\title{
PENGARUH RELIGIUSITAS DAN ETHICAL CLIMATE TERHADAP ETHICAL BEHAVIOR
}

\author{
Fauzan \\ Email : fauzan@unikama.ac.id
}

\begin{abstract}
Abstrak : Tujuan dari penelitian ini adalah untuk mengukur pengaruh religiusitas dan ethical climate terhadap ethical behavior. Metode penelitian ini adalah kuantitatif. Populasi penelitian adalah mahasiswa internasional Master dan Ph.D pada Graduate School of Business Othman Yeop Abdullah Universiti Utara Malaysia. Teknik pengambilan sampel menggunakan non-probability sampling dengan teknik pemilihan sampel adalah accidental sampling. Ada 31 responden yang mengisi kuesioner. Hasil penelitian menunjukkan secara sendiri-sendiri (parsial) bahwa religiusitas memiliki pengaruh yang positif tidak signifikan terhadap perilaku etis. Ethical climate memiliki pengaruh yang positif dan signifikan terhadap perilaku etis. Sementara secara bersama-sama (simultan) religiusitas dan ethical climate memiliki pengaruh yang positif dan signifikan terhadap perilaku etis.
\end{abstract}

Kata Kunci: religiusitas, ethical climate, ethical behavior

\section{PENDAHULUAN}

Penerapan etika dalam organisasi sangat penting dan perlu diimplementasikan dalam berbagai aktivitas kehidupan untuk menciptakan nilai moral yang baik. Etika sebagai modal utama moralitas dalam kehidupan yang menuntut untuk berbuat baik (Aristoteles, 1953). Etika bukan hanya sekedar konsep untuk dipahami, namun harus menjadi bagian dari diri dan diterapkan dalam berbagai aktivitas kehidupan (Suseno, 1987). Etika dapat dirumuskan sebagai suatu batasan yang menilai tentang salah atau benar serta baik atau buruk suatu tindakan (Bertens, 2000). Etika yang baik, mencerminkan perilaku yang baik, sedangkan etika yang buruk, mencerminkan perilaku yang buruk pula. Etika menjadikan individu lebih bertanggung jawab, adil dan responsive. Etika merupakan kebiasaan yang benar dalam pergaulan.

Salah satu sumber etika adalah agama. Agama diarahkan untuk memantapkan fungsi dan perannya sebagai landasan moral dan etika dalam bermasyarakat. Penelitian terdahulu menyatakan bahwa keberagamaan (religiosity) diketahui sebagai salah satu determinant yang mempengaruhi perilaku yang beretika. Keberagamaan memiliki peran dalam mempengaruhi perilaku social seseorang (Allport \& Ross, 1967; Allport, 1967). Mcmahon (1986) percaya bahwa keberagamaan memberikan kontribusi pada etika bisnis. Keberagamaan memiliki hubungan yang positif dengan ideology etis yang memberikan kontribusi positif

Fauzan, adalah Dosen Prodi Akuntansi FEB Universitas Kanjuruhan Malang 
pada niat untuk berperilaku (Barnett, Bass, \& Brown, 1996). (Weaver \& Agle, 2002) menyatakan bahwa ada hubungan yang signifikan antara keberagamaan dan perilaku.

Pada hakekatnya Perilaku yang Beretika (ethical behavior) berisi tentang keharusan yang wajib dilaksanakan dan larangan yang harus dihindari. Maksud dan tujuan Perilaku yang Beretika ini tidak hanya untuk memastikan bahwa organisasi telah mematuhi semua peraturan organisasi dan perundang-undangan yang terkait, namun memberikan panduan bagi organisasi atau anggota dalam melakukan interaksi berdasarkan nilai-nilai moral yang merupakan bagian dari budaya organisasi.

Nilai-nilai yang dianut oleh organisasi harus mendukung Visi, Misi, Tujuan, dan Strategi Organisasi serta harus diterapkan terlebih dahulu oleh jajaran pimpinan organisasi untuk selanjutnya meresap ke dalam jajaran organisasi. Perilaku yang Beretika perlu diterapkan untuk menjaga berlangsungnya lingkungan kerja yang profesional, jujur, terbuka, peduli, dan tanggap terhadap setiap kegiatan organisasi serta kepentingan pihak stakeholders.

Salah satu tujuan kajian etika dalam organisasi adalah untuk memastikan bahwa oranisasi dapat menjalakan kegiatan operasionalnya dengan baik dan lancar, mampu meraih keuntungan dan berkembang di masa depan, serta terciptanya hubungan yang harmonis antara organisasi dengan anggotanya. Untuk menciptakan hubungan kerjasama yang harmonis, organisasi menetapkan suatu pedoman tentang Perilaku yang Beretika (Code of Conduct) yang memuat nilainilai etika.

Selain itu nilai-nilai etika dalam organisasi juga disebakan oleh adanya perbedaan budaya atau ethical climate dalam organisasi tersebut. Ethical climate yang dirasakan dalam organisasi juga mempengaruhi kemungkinan perilaku tidak etis yang akan mempengaruhi komitmen organisasi. Ethical climate telah dipelajari selama lebih dari dua dekade dalam perilaku organisasi dan literatur bisnis (Victor and Cullen, 1987, 1988; Trevino et al, 1998 dalam Shafer, 2008) dan hasil kolektif dari banyak penelitian mengindikasikan bahwa iklim yang dirasakan dalam suatu organisasi mempengaruhi kemungkinan perilaku yang tidak etis dan hasil tidak efektif sehingga juga akan mempengaruhi komitmen organisai (Martin and Cullen, 2006 dalam Shafer, 2008).

\section{TINJAUAN PUSTAKA}

\section{Ethical Behavior}

Etika merupakan filsafat atau pemikiran kritis dan mendasar tentang ajaran dan pandangan moral (Suseno, 1987). Etika juga merupakan tingkah laku atau aturan-aturan tingkah laku yang diterima dan digunakan oleh individual atau suatu golongan tertentu (Khomsiyah \& Indriantoro, 1998). Etika merupakan pedoman, atau ukuran berperilaku yang tercipta melalui konsensus atau keagamaan atau kebiasaan yang didasarkan pada nilai baik dan buruk (Desriani, 1993). Etika merupakan keyakinan mengenai tindakan yang benar dan yang salah, atau tindakan yang baik dan yang buruk, yang mempengaruhi hal lainnya (Griffin \& Ebert, 2007). Perilaku etis adalah perilaku yang sesuai dengan norma-norma 
sosial yang diterima secara umum sehubungan dengan tindakan-tindakan yang benar dan baik. Perilaku etis ini dapat menentukan kualitas individu (karyawan) yang dipengaruhi oleh faktor-faktor yang diperoleh dari luar yang kemudian menjadi prinsip yang dijalani dalam bentuk perilaku.

Faktor-faktor yang mempengaruhi perilaku etis yaitu: (1) Budaya organisasi. Budaya organisasi merupakan sistem makna bersama yang dianut oleh anggota-anggota yang membedakan organisasi itu dari organisasi yang lain. Dengan demikian budaya organisasi adalah nilai yang dirasakan bersama oleh anggota organisasi yang diwujudkan dalam bentuk sikap perilaku pada organisasi. (2) Kondisi politik. Kondisi politik merupakan rangkaian asas atau prinsip, keadaan, jalan, cara atau alat yang akan digunakan untuk mencapai tujuan. (3) Perekonomian global. Perekonomian global merupakan kajian tentang pengurusan sumber daya materian individu, masyarakat, dan negara untuk meningkatkan kesejahteraan hidup manusia

Beberapa penelitian menyatakan bahwa, perilaku yang beretika merupakan fungsi yang penting dalam pengelolaan organisasi (Ruiz-Palomino \& MartínezCañas, 2011). Perilaku yang beretika menjadi hal yang penting dalam berbagai aktivitas kehidupan, meskipun dalam beberapa kasus penyimpangan etika masih banyak terjadi. Hal ini perlu dipikirkan kembali efesiensi strategi etika yang ada. Diantaranya adalah masih terjadinya kasus korupsi di berbagai perusahaan, terutamanya di pemerintahan. Korupsi menjadi isu yang menarik untuk dikaji, karena korupsi merupakan perilaku yang tidak beretika dalam aktivitas perusahaan maupun pemerintahan.

Menurut Kreitner \& Kinicki (2001) dan Hunt \& Vitell (1986), perilaku etis dan tidak etis adalah produk dari kombinasi yang rumit dari berbagai pengaruh. Individu mempunyai kombinasi unik dari karakterisik personalitas, nilai-nilai, prinsip-prinsip moral, pengalaman pribadi. Perilaku Etis yang dimaksud dalam penelitian ini merupakan nilai-nilai tingkah laku atau aturanaturan tingkah laku yang diterima dan digunakan oleh seseorang atau profesi yang meliputi kepribadian, kecakapan professional, tanggung jawab, kejujuran, keadilan, pelaksanaan kode etik, dan penafsiran dan penyempurnaan kode etik .

\section{Religusitas}

Keagamaan atau religiusitas diwujudkan dalam berbagai sisi kehidupan manusia. Agama merupakan salah satu lembaga sosial yang paling universal dan memiliki pengaruh signifikan terhadap sikap masyarakat, nilai-nilai, dan perilaku baik di tingkat individu dan masyarakat (Mokhlis, 2009). Menurut Kotler (2000) agama adalah bagian dari budaya yang dapat membentuk perilaku masyarakat. Artinya, bahwa orang yang memiliki agama akan memegang nilai-nilai tertentu yang dapat mempengaruhi tindakan dan keputusan mereka (Alam, Mohd, \& Hisham, 2011). Agama memiliki peran penting dalam kehidupan seseorang dengan membentuk keyakinan, pengetahuan, dan sikap mereka (Rehman \& Shabbir, 2010).

Tingkat keagamaan seseorang sulit diukur (Schutte \& Hosch, 1996), karena memiliki beberapa definisi. Menurut Caird (1987) Ada tiga ukuran dari keagamaan : Kognitif (fokus pada sikap atau keyakinan agama), perilaku (mengevaluasi kehadiran ditempat ibadah dan doa pribadi), dan pengalaman (pengalaman mistik). Mookherjee (1993) mendefinisikan keagamaan sebagai 
aktivitas public dan partisipatif (berdasarkan keanggotaan gereja dan kehadiran di gereja), dan perilaku keagamaan pribadi (berdasarkan frekuensi doa, membaca alkitab, dan intensitas ibadah) (Barhem, Younies, \& Muhamad, 2009).

Cornwall, Albrecht, Cunningham, \& Pitcher (1986) mendefinisikan Keagamaan dalam hal : (1) Cognition (ilmu agama, keyakinan agama). (2) Affect (yang berkaitan dengan ikatan emosional atau perasaan emosional tentang agama.

(3) Behavior (berkaitan dengan afiliasi dan kehadiran di gereja, membaca al-kitab, dan berdoa). Bellah (1991) memberi makna keagamaan adalah seperangkat bentuk simbolis dan tindakan manusia yang berhubungan dengan kondisi akhir dari keberadaannya. Sementara Beit-Hallahmi \& Argyle (1997) menyatakan bahwa keagamaan adalah sebuah sistem keyakinan dalam kekuatan ilahi yang maha besar dan praktik ibadah atau ritual lainnya yang diarahkan kepada kekuatan tersebut. Dan Dollahite (1998) mendefinisikan keagamaan merupakan sebuah komunitas perjanjian iman dengan ajaran dan narasi yang meningkatkan pencarian sakral.

Penelitian terdahulu menyatakan bahwa keberagamaan (religiosity) diketahui sebagai salah satu determinant yang mempengaruhi perilaku yang beretika. Keberagamaan memiliki peran dalam mempengaruhi perilaku social seseorang (Allport \& Ross, 1967; Allport, 1967). Mcmahon (1986) percaya bahwa keberagamaan memberikan kontribusi pada etika bisnis. Keberagamaan memiliki hubungan yang positif dengan ideology etis yang memberikan kontribusi positif pada niat untuk berperilaku (Barnett et al., 1996). (Weaver \& Agle, 2002) menyatakan bahwa ada hubungan yang signifikan antara keberagamaan dan perilaku. Ada perbedaan yang signifikan dari tingkat keberagamaan seseorang dalam memilih layanan perbankan islam (Ahmad, Rahman, Ali, \& Seman, 2008). Keberagamaan menjadi determinan penting dalam perilaku konsumen (Alam, Janor, Zanariah, Wel, \& Ahsan, 2012). Keberagamaan memiliki pengaruh untuk berperilaku dalam menghindari pajak. Keberagamaan adalah determinant penting perilaku penghindaran pajak oleh pembayar pajak perusahaan dan individu (Boone, Khurana, \& Raman, 2012).

Dalam penelitian ini, mengacu kepada konsep keagamaan yang diungkapkan oleh McDaniel \& Burnett (1990), bahwa keagamaan dianggap sebagai keyakinan seseorang pada Tuhan yang disertai dengan komitmen untuk bertindak sesuai dengan prinsip-prinsip yang diyakini dan telah ditetapkan oleh Tuhan (Clark \& Dawson, 1996; Weaver \& Agle, 2002). Dimensi keagamaan bisa diukur dari komitmen keagamaannya (Glock, 1962; Stark \& Glock, 1968). Komitmen keagamaan didefinisikan oleh Johnson, Jang, Larson, \& Li (2001) sebagai komitmen seorang individu terhadap agama dan ajaran-ajarannya, seperti sikap dan perilaku individu yang mencerminkan komitmen tersebut. Adapun dimensi keagamaan menurut Stark \& Glock (1968), yaitu: ideological, ritualistic, intellectual, experiential, consequential

\section{Ethical Climate}

Teori iklim etika (ethical climate theory) pertama diusulkan oleh Victor dan Cullen $(1987,1988)$. Ini adalah konsep untuk memahami sistem normatif organisasi. Pada saat itu, ada kebutuhan mendesak untuk mengembangkan alat tersebut (Victor \& Cullen, 1988), ethical climate mendiskripsikan dari nilai-nilai 
dalam organisasi dan bagaimana para karyawan bertanggung jawab atas perilaku etis atau tidak etis dalam organisas tersebut (Simha dan Cullen, 2012).

Teori iklim etika (ethical climate theory) yang dikembangkan oleh Victor dan Cullen $(1987,1988)$ berdasarkan pada pandangan Kohlberg (1984) yang membahas tentang perkembangan moral dan Schneider (1983) yang membahas pada teori sosial budaya organisasi. Awalnya Victor dan Cullen (1988) membuat framework yang terdiri dari model dua dimensi dari tipe iklim etika, yaitu filsafat etika dan teori sosiologi (Simha dan Cullen, 2012).

Dimensi filsafat etika mencakup tiga kriteria: egoisme, kebajikan, dan prinsip. Egoisme mengacu pada perilaku yang berkaitan terutama dengan kepentingan diri. Kebajikan mirip dengan utilitarianisme, dalam keputusan dan tindakan yang diambil untuk menghasilkan kebaikan terbesar kepada semua orang. Prinsip ini mirip dengan deontologi, dalam keputusan yang dibuat dan tindakan yang diambil sesuai dengan undang-undang, peraturan, kode, dan prosedur. Ketiga kriteria etis ini merupakan dimensi filsafat etika dari kerangka ECT.

Teori sosiologis terdiri dari tiga lokus dimensi, yaitu: individu, lokal, dan kosmopolitan. Lokus ini mengacu pada keputusan seseorang membuat berdasarkan keyakinan pribadi mereka sendiri dan nilai-nilai, organisasi itu sendiri, dan komunitas atau masyarakat eksternal organisasi. Kombinasi dari dimensi teoritis iklim etika menghasilkan sembilan jenis iklim teoritis (lihat Gambar 1), kepentingan pribadi, laba perusahaan, efisiensi, persahabatan, kepentingan kelompok, tanggung jawab sosial, moralitas pribadi, aturan dan prosedur perusahaan, dan hukum dan profesional kode (Simha dan Cullen (2012).

Menurut (Bulutlar \& Oz, 2009; Martin \& Cullen, 2006; Tsai \& Huang, 2008), secara empiris, lima jenis iklim etika paling sering terjadi: instrumental, peduli, kemerdekaan, hukum dan kode, dan aturan (lihat Gambar 2). jenis iklim etika, terjadi secara empiris, berasal dari sembilan jenis iklim teoritis dan beberapa lokus analisis. Misalnya, iklim etika bisa dibentuk dengan kedua kepentingan dan keuntungan perusahaan. Iklim Instrumental dijelaskan sebagai iklim yang terkait dengan membangun egoisme dan analisi lokus lokal individu; karyawan yang bekerja di sebuah organisasi mengharapkan bahwa organisasi akan memiliki norma-norma dan harapan yang mendorong keputusan etis, dari perspektif egoistik. Iklim peduli digambarkan sebagai iklim yang terkait dengan membangun kebaikan dan lokus individu dan lokal analisis; karyawan yang bekerja di iklim peduli dirasakan bahwa keputusan mereka dan harus didasarkan pada kebaikan dan kesejahteraan orang lain. iklim ini cenderung mendorong perilaku yang menghasilkan hasil yang positif bagi orang lain. Iklim kemerdekaan dijelaskan sebagai iklim yang terkait dengan membangun prinsip dan analisis lokus individu; untuk membuat keputusan etis, karyawan percaya bahwa mereka dapat bertindak pada keyakinan personal yang dipegang. Iklim Kemerdekaan menyatakan bahwa keyakinan moral pribadi lebih penting daripada pengaruh eksternal.

Tabel 1. Theoretical Strata of Ethical Climate LOCUS OF ANALYSIS

\begin{tabular}{|l|l|l|l|l|}
\hline & & Individual & Local & Cosmopolitan \\
\hline $\begin{array}{l}\text { ETHICAL } \\
\text { THEORY }\end{array}$ & Egoism & Self- & Company Profit & Efficiency \\
\hline
\end{tabular}


192 MODERNISASI, Volume 11, Nomor 3, Oktober 2015

\begin{tabular}{|l|l|l|l|l|}
\hline & & Individual & Local & Cosmopolitan \\
\hline & Benevolence & Friendship & Team Interest & $\begin{array}{l}\text { Social } \\
\text { Responsibility }\end{array}$ \\
\cline { 2 - 5 } & Principle & $\begin{array}{l}\text { Personal } \\
\text { Morality }\end{array}$ & $\begin{array}{l}\text { Company Rules } \\
\text { and Procedures }\end{array}$ & $\begin{array}{l}\text { Laws and } \\
\text { Professional Codes }\end{array}$ \\
\hline
\end{tabular}

Source: Adapted (Simha and Cullen, 2012)

Tabel 2. Five Common Empirical Derivatives of Ethical Climate LOCUS OF ANALYSIS

\begin{tabular}{|c|l|l|l|l|}
\hline & & Individual & Local & Cosmopolitan \\
\hline \multirow{2}{*}{ ETHICAL } & Egoism & Instrumental & Instrumental & \\
\cline { 2 - 5 } ANALYSIS & Benevolence & Caring & Caring & \\
\cline { 2 - 5 } & Principle & Independence & Rules & Law and Codes \\
\hline
\end{tabular}

Source: Adapted (Simha and Cullen, 2012)

Iklim yang Beretika (ethical climate) adalah persepsi yang berlaku secara khas dalam organisasi berupa praktek dan prosedur yang memiliki kandungan nilai-nilai yang beretika (Cullen, Victor, \& Bronson, 1993). Iklim yang beretika adalah konstruk yang memiliki multi-dimensi yang mengidentifikasi system normative dalam sebuah organisasi sebagai petunjuk dalam pengambilan keputusan dan untuk menyikapi dilema etika. Oleh karenanya iklim yang beretika diukur dengan lima item yaitu : caring, law and rules, service, independence, dan instrumental.

Menurut landasan teori mengenai perilaku etis (ethical behavior), keberagamaan (religiosty), dan iklim etis (ethical climate), maka dapat disusun kerangka pikir gambar 3 sebagai berikut :

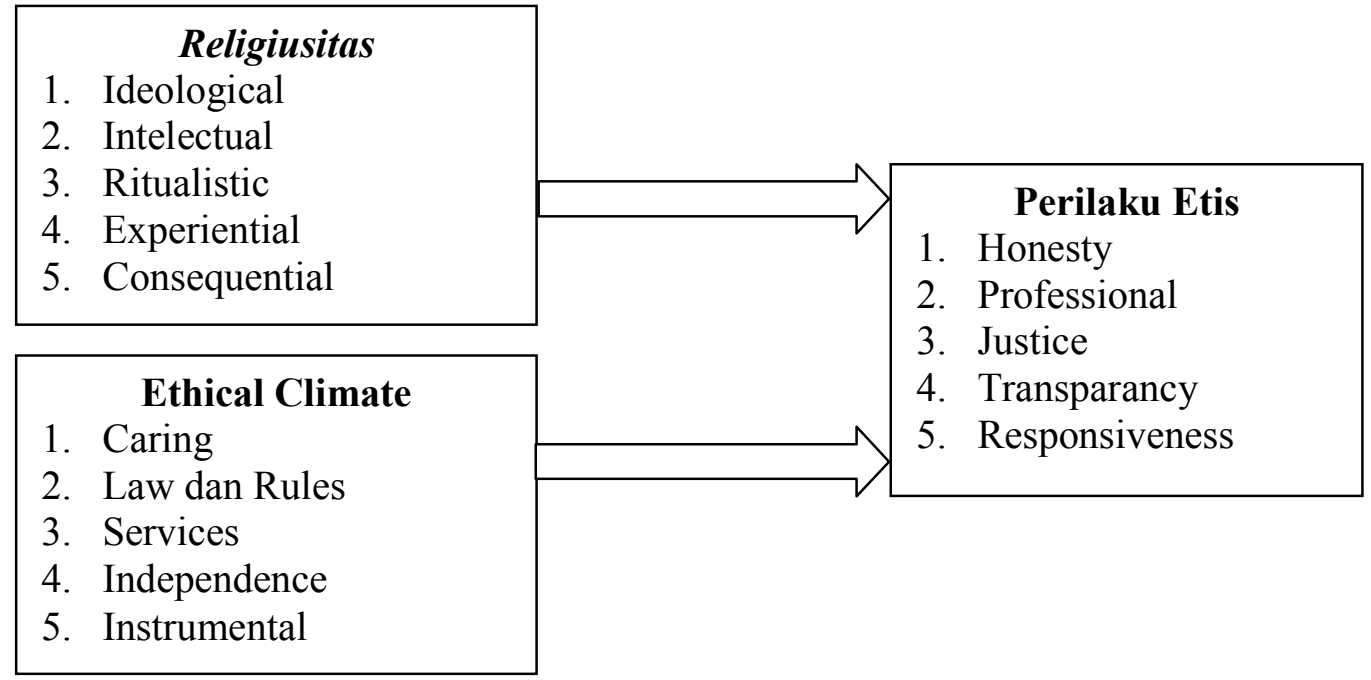

Gambar 1. Kerangka Pikir Penelitian 
Dari kerangka pikir tersebut disusun kerangka konseptual penelitian sebagai berikut:

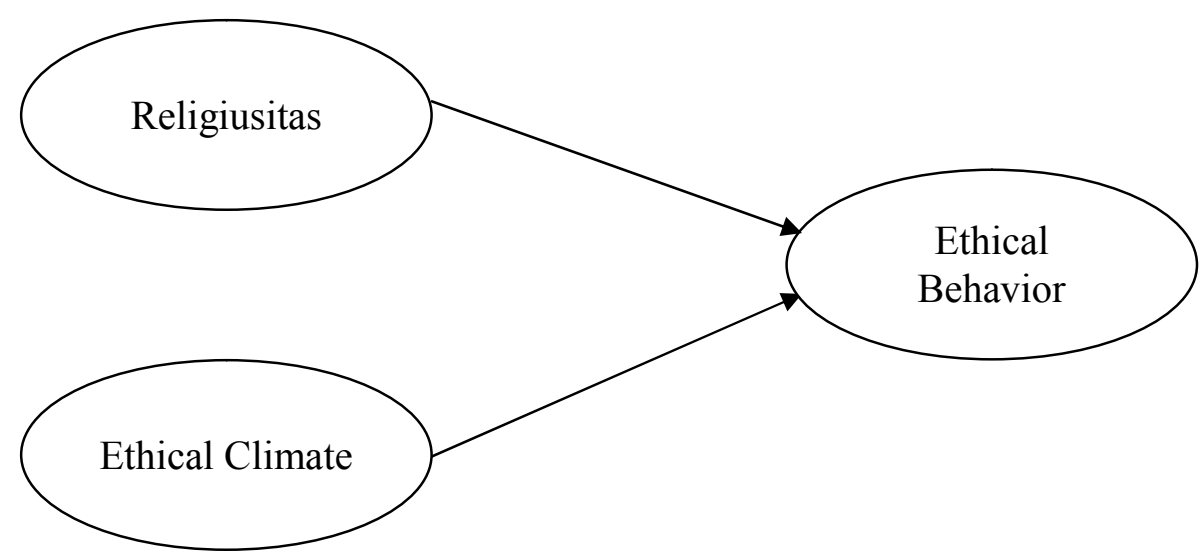

Gambar 2. Kerangka Konseptual Penelitian

Bedasarkan kerangka pemikiran dan rumusan masalah di atas, maka dikembangkan hipotesis penelitian sebagai berikut :

a. Religiusitas berpengaruh positif dan signifikan terhadap Perilaku Etis (ethical behavior)

b. Iklim yang Beretika (ethical climate) berpengaruh positif dan signifikan terhadap Perilaku Etis (ethical behavior)

c. Religiusitas dan Iklim yang Beretika (ethical climate) berpengaruh positif dan signifikan terhadap Perilaku Etis (ethical behavior)

\section{METODE}

Metode yang digunakan dalam penelitian ini bersifat kuantitatif. Menurut Malhotra $(2004,2010)$ penelitian kuantitatif adalah metodologi penelitian yang mencari kuantitas data dan biasanya, berlaku beberapa analisis yang digunakan untuk statistik. Jenis penelitian yang digunakan adalah penelitian eksplanatori kausal. Menurut Umar (2008) penelitian eksplanatori (explanatory research) adalah penelitian yang bertujuan untuk menganalisis hubungan-hubungan antara satu variabel dengan variabel lainnya atau bagaimana suatu variabel mempengaruhi variabel lainnya. Penulis menggunakan metode eksplanatori kausal untuk menjelaskan hubungan pengaruh antar variabel sehingga mendapatkan informasi spesifik mengenai dampak religiusitas dan ethical climate terhadap ethical behavior.

Desain penelitian ini adalah survey. Data yang dibutuhkan dalam penelitian ini adalah data primer dalam bentuk persepsi responden (subjek) penelitian. Pengambilan data menggunakan survey langsung dan instrumen yang digunakan adalah kuesioner (angket). Menurut Malhotra (2004) kuesioner adalah teknik terstruktur untuk pengumpulan data yang terdiri dari serangkaian pertanyaan, 
tertulis atau lisan, untuk menanggapi jawaban. Kuesioner ini digunakan sebagai instrumen penelitian untuk mengetahui bagaimana hubungan antara Religiusitas dan Ethical Climate terhadap Ethical Behavior.

Tabel 3. Pengukuran Operasional Variabel

\begin{tabular}{|l|l|l|c|}
\hline \multicolumn{1}{|c|}{ Variabel } & \multicolumn{1}{|c|}{ Cara pengukuran } & Skala & \multicolumn{1}{|c|}{$\begin{array}{c}\text { Sumber } \\
\text { Data }\end{array}$} \\
\hline Religiusitas & $\begin{array}{l}\text { Aspek religiusitas diukur dengan 5 } \\
\text { dimensi, yaitu: ideological, } \\
\text { intelectual, ritualistic, experiential, } \\
\text { dan consequential (Glock, 1962; Stark } \\
\text { \& Glock, 1968). menggunakan skala } \\
\text { Likert (1-5) }\end{array}$ & Primer \\
\hline Ethical Climate & $\begin{array}{l}\text { Konsep ethical climate diukur dengan } \\
5 \text { dimensi, yaitu: caring, law dan rules, } \\
\text { services, independence, dan } \\
\text { instrumental (Cullen et al., 1993). } \\
\text { menggunakan skala Likert (1-5) }\end{array}$ & & Primer \\
\hline Ethical Behavior & $\begin{array}{l}\text { Aspek ethical behavior diukur dengan } \\
5 \text { dimensi, yaitu: honesty, profesional, } \\
\text { justice, transparancy, dan } \\
\text { responsiveness (Karami, Olfati, \& } \\
\text { Dubinsky, 2014). menggunakan skala } \\
\text { Likert (1-5) }\end{array}$ & & \\
\hline
\end{tabular}

Sumber: Peneliti

Populasi penelitian ini adalah mahasiswa internasional Master dan Ph.D pada Graduate School of Business Othman Yeop Abdullah Universiti Utara Malaysia. Teknik pengambilan sampel dalam penelitian ini menggunakan teknik non-probability sampling, dimana semua populasi tidak memiliki peluang yang sama untuk menjadi responden (Sugiyono, 2007). Dan dengan pertimbangan untuk menghemat waktu dan biaya, maka teknik pemilihan sampel pada penelitian ini adalah metode acciidental sampling, yaitu teknik memilih sampel berdasarkan kebetulan, yaitu siapa saja yang secara kebetulan bertemu dengan peneliti dapat digunakan sebagai sampel, bila dipandang orang yang kebetulan ditemui itu cocok sebagai sumber data (Sekaran \& Bougie, 2013).

Teknis analisis data yang digunakan untuk menjawab rumusan masalah dalam penelitian ini adalah menggunakan Regresi Linear Berganda, dengan bantuan software SPSS 20.

\section{PEMBAHASAN}

\section{Analisis Deskriptif}

Hasil analisis data deskriftif mengenai demografi responden dapat dilihat pada tabel 4 . Di antara 31 responden, $(77.42 \%)$ atau 24 orang adalah laki-laki dan $(22.58 \%)$ atau 7 orang adalah perempuan. Mayoritas responden $(32.26 \%)$ atau 10 orang berada dalam kelompok umur antara 36-40. Di sisi lain, (16.13\%) usia dari 
responden berada di kisaran 31-35 tahun sebanyak 5 orang, sebanyak $(6.45 \%)$ atau sekitar 2 orang berada pada usia antara 26-30 tahun, sebanyak (16.13\%) atau 5 orang berada pada usia kurang dari 25 tahun, dan sisanya (29.03\%) atau sekitar 9 orang berusia di atas 40 tahun. Etnis reponden sebanyak $(16,13 \%)$ atau 5 orang berasal dari Malaysia, sebanyak (6,45\%) atau sebanyak 2 orang berasal dari China, dan sebanyak $(77,42 \%)$ berasal dari negara lain iaitu, Pakistan, Iraq, Yaman, Jordan, dan Nigeria. Mayoritas responden menempuh pendidikan Master $(51,61 \%)$ atau 16 orang, diikuti oleh responden yang menempuh pendidikan Ph.D $(48,39 \%)$ sebanyak 15 orang.

Table 4. Demographic profile of respondents

\begin{tabular}{|c|l|c|c|}
\hline Profile & \multicolumn{1}{|c|}{ Kategori } & Frekuensi & \% \\
\hline \multirow{4}{*}{ Gender } & Male & 24 & 77.42 \\
\cline { 2 - 4 } & Female & 7 & 22.58 \\
\hline \multirow{4}{*}{ Age } & Less than 25 years & 5 & 16.13 \\
\cline { 2 - 4 } & $26-30$ years & 2 & 6.45 \\
\cline { 2 - 4 } & $31-35$ years & 5 & 16.13 \\
\cline { 2 - 4 } & $36-40$ years & 10 & 32.26 \\
\cline { 2 - 4 } & 40 years and above & 9 & 29.03 \\
\hline \multirow{4}{*}{ Etnicity } & Malay & 5 & 16.13 \\
\cline { 2 - 4 } & Chinese & 2 & 6.45 \\
\cline { 2 - 4 } & Indian & 24 & 77.42 \\
\cline { 2 - 4 } & Other & 0 & 51.61 \\
\hline \multirow{3}{*}{ Education } & Degree & 16 & 48.39 \\
\cline { 2 - 4 } & Master & 15 & \\
\cline { 2 - 4 } & Ph.D & & \\
\hline
\end{tabular}

Notes : $\mathrm{n}=31$

\section{Hasil Analisis Validitas dan Reliabilitas}

Tabel 5. Validitas

\begin{tabular}{|c|c|c|c|c|}
\hline Variable & Item & $\mathbf{r}_{\mathbf{x y}}$ & $\mathbf{r}_{\text {tabel }}$ & Keterangan \\
\hline \multirow{4}{*}{$\begin{array}{c}\text { Religiousity } \\
\text { (X1) }\end{array}$} & $\mathrm{X}_{1-1}$ & 0.541 & 0.355 & Valid \\
\cline { 2 - 5 } & $\mathrm{X}_{1-2}$ & 0.309 & 0.355 & Not Valid \\
\cline { 2 - 5 } & $\mathrm{X}_{1-3}$ & 0.621 & 0.355 & Valid \\
\cline { 2 - 5 } & $\mathrm{X}_{1-4}$ & 0.756 & 0.355 & Valid \\
\cline { 2 - 5 } & $\mathrm{X}_{1-5}$ & 0.666 & 0.355 & Valid \\
\cline { 2 - 5 } & $\mathrm{X}_{1-6}$ & 0.488 & 0.355 & Valid \\
\cline { 2 - 5 } & $\mathrm{X}_{1-7}$ & 0.674 & 0.355 & Valid \\
\cline { 2 - 5 } & $\mathrm{X}_{1-8}$ & 0.457 & 0.355 & Valid \\
\cline { 2 - 5 } & $\mathrm{X}_{1-9}$ & 0.796 & 0.355 & Valid \\
\hline Ethical Climate & $\mathrm{X}_{2-1}$ & 0.596 & 0.355 & Valid \\
\hline
\end{tabular}


196 MODERNISASI, Volume 11, Nomor 3, Oktober 2015

\begin{tabular}{|c|c|c|c|c|}
\hline Variable & Item & $\mathbf{r}_{\mathbf{x y}}$ & $\mathbf{r}_{\text {tabel }}$ & Keterangan \\
\hline \multirow{4}{*}{$(\mathbf{X 2 )}$} & $\mathrm{X}_{2-2}$ & 0.705 & 0.355 & Valid \\
\cline { 2 - 5 } & $\mathrm{X}_{2-3}$ & 0.690 & 0.355 & Valid \\
\cline { 2 - 5 } & $\mathrm{X}_{2-4}$ & 0.727 & 0.355 & Valid \\
\cline { 2 - 5 } & $\mathrm{X}_{2-5}$ & 0.609 & 0.355 & Valid \\
\cline { 2 - 5 } & $\mathrm{X}_{2-6}$ & 0.497 & 0.355 & Valid \\
\cline { 2 - 5 } & $\mathrm{X}_{2-7}$ & 0.458 & 0.355 & Valid \\
\cline { 2 - 5 } & $\mathrm{X}_{2-8}$ & 0.548 & 0.355 & Valid \\
\cline { 2 - 5 } & $\mathrm{X}_{2-9}$ & 0.678 & 0.355 & Valid \\
\cline { 2 - 5 } & $\mathrm{X}_{2-10}$ & 0.823 & 0.355 & Valid \\
\hline \multirow{4}{*}{ Ethical Behavior } & $\mathrm{Y}_{1-1}$ & 0.884 & 0.355 & Valid \\
\cline { 2 - 5 } & $\mathrm{Y}_{1-2}$ & 0.840 & 0.355 & Valid \\
\cline { 2 - 5 } & $\mathrm{Y}_{1-3}$ & 0.927 & 0.355 & Valid \\
\cline { 2 - 5 } & $\mathrm{Y}_{1-4}$ & 0.708 & 0.355 & Valid \\
\cline { 2 - 5 } & $\mathrm{Y}_{1-5}$ & 0.871 & 0.355 & Valid \\
\cline { 2 - 5 } & $\mathrm{Y}_{1-6}$ & 0.845 & 0.355 & Valid \\
\cline { 2 - 5 } & $\mathrm{Y}_{1-7}$ & 0.675 & 0.355 & Valid \\
\cline { 2 - 5 } & $\mathrm{Y}_{1-8}$ & 0.752 & 0.355 & Valid \\
\hline
\end{tabular}

Notes $: \mathrm{n}=31, \alpha=0.05(\mathrm{t}=0.355)$

Tabel 6. Reliabilitas

\begin{tabular}{|c|c|c|c|}
\hline No. & Variable & $\begin{array}{c}\text { Coeffecient } \text { Alpha } \\
\text { Cronbach }\end{array}$ & \\
\hline 1 & Religiosity (X1) & 0.771 & Reliable \\
\hline 2 & Ethical Climate (X2) & 0.838 & Reliable \\
\hline 3 & Ethical Behavior (Y) & 0.928 & Reliable \\
\hline
\end{tabular}

Alpha Cronbach $>0.6$

Hasil analisis Validitas menunjukkan bahwa nilai t-hitung dari semua item $>\mathrm{t}$ tabel (nilai t-tabel pada $\mathrm{n}=31, \alpha=0.05$ adalah $\mathrm{t}=0,355$ ). kecuali pada item X1-2 tidak valid. Sementara untuk hasil analisis reliabilitas, semua variabel reliabel, dengan nilai Alfa Cronbach $>0.60$.

\section{Asumsi Klasik}

Hasil dari uji asumsi klasik menunjukkan bahwa tidak adanya gejala multikolinieritas, dan autokrelasi, serta data normal dan tidak terjadi heteroskedastisitas.

Tabel 7. Uji Multikolinieritas dan Autokorelasi

\begin{tabular}{|c|c|c|}
\hline \multirow{4}{*}{ Collinearity Statistics } & \multirow[t]{2}{*}{ Tolerance } & .746 \\
\hline & & .746 \\
\hline & \multirow[t]{2}{*}{ VIF } & 1.341 \\
\hline & & 1.341 \\
\hline Autocorrelations & Durbin-Watson & 1.903 \\
\hline
\end{tabular}




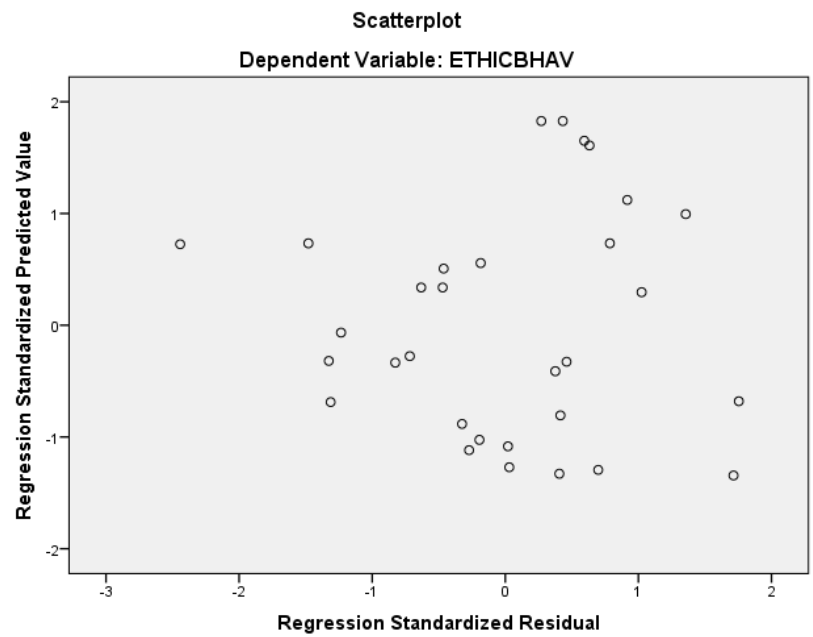

Gambar 3. Result of Heteroscedasticity

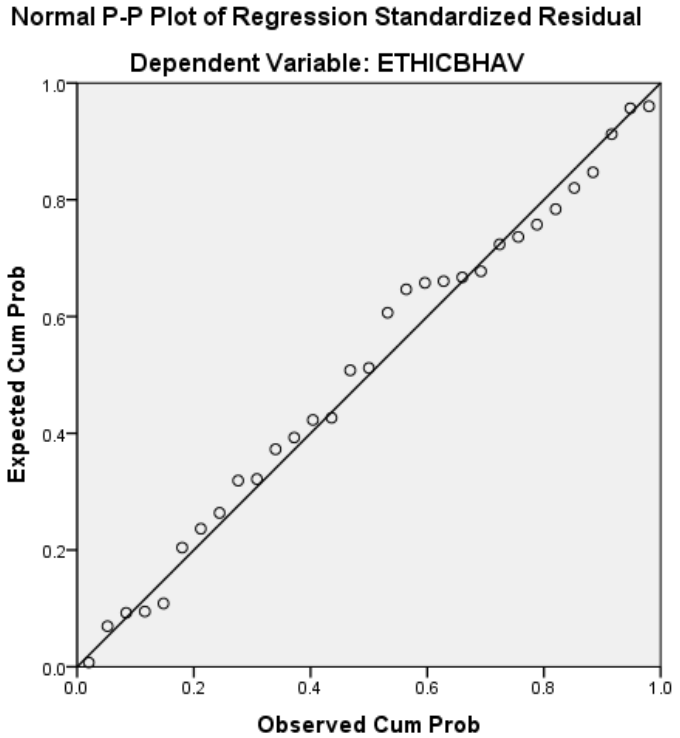

Gambar 4. Result of Normality

\section{Hasil Uji Hipotesis}

Uji regresi antara religiusitas (x1), ethical climate $(\mathrm{x} 2)$ dan perilaku etis (y) ditunjukkan pada tabel 8 di bawah ini. Analisis regresi berganda digunakan untuk menguji H1, H2, H3. Hasil pengujian diilustrasikan pada Tabel 8. 
198 MODERNISASI, Volume 11, Nomor 3, Oktober 2015

Tabel 8. Results of Multiple Regression Analysis

\begin{tabular}{|c|l|c|c|c|}
\hline $\begin{array}{c}\text { Dependent } \\
\text { variable }\end{array}$ & \multicolumn{1}{|c|}{$\begin{array}{c}\text { Independent } \\
\text { variable }\end{array}$} & Std. Beta & $\mathrm{t}$ & Sig. \\
\hline \multirow{4}{*}{$\begin{array}{c}\text { Ethical } \\
\text { Behavior }\end{array}$} & Constant & -22.857 & & \\
\cline { 2 - 5 } & Religiosity & 0.239 & 0.805 & 0.428 \\
\cline { 2 - 5 } & Ethical Climate & 0.998 & 3.862 & 0.001 \\
\cline { 2 - 5 } & $\mathrm{R}$ & \multicolumn{3}{|c|}{0.687} \\
\cline { 2 - 5 } & R2 & \multicolumn{3}{|c|}{0.473} \\
\cline { 2 - 5 } & Adjusted R2 & \multicolumn{3}{|c|}{0.541} \\
\hline & F - hitung & \multicolumn{3}{|c|}{0.000} \\
\hline
\end{tabular}

Analisis regresi berganda ini digunakan untuk melihat efek dari religiusitas dan ethical climate pada perilaku etis. Hasil pada tabel 8 menunjukkan bahwa religiusitas (religiosity) mempunyai pengaruh positif dan tidak signifikan terhadap perilaku etis $(\beta=0,239, p>\alpha=0,428)$. Di sisi lain, menunjukkan bahwa ethical climate memiliki pengaruh yang signifikan dan positif terhadap perilaku etis. ( $\beta=$ $0,998, \mathrm{p}<0,001)$. Dan secara bersama-sama (simultan) religiusitas dan ethical climate memiliki pengaruh yang positif dan signifikan terhadap perilaku etis mahasiswa Graduate School of Business Othman Yeop Abdullah, Universiti Utara Malaysia (F-hitung $=12.541 ; \mathrm{p}<\alpha=0,000$ ). Dengan demikian H2 dan H3 didukung, sementara $\mathrm{H} 1$ tidak didukung.

Hasil penelitian ini mendukung beberapa penelitian terdahulu yang menyatakan bahwa tidak ada hubungan antara keberagamaan dan keputusan yang beretika (Kidwell, Stevens, \& Bethke, 1987). Clark \& Dawson (1996) mendapatkan bahwa ada hubungan negative antara keberagamaan dan pertimbangan etika bisnis. Keberagamaan tidak mempengaruhi secara langsung penilaian etis terhadap perilaku yang beretika (Bakar, Lee, \& Hashim, 2013). Keberagamaan memiliki hubungan yang lemah sebagai factor pembentuk kepemimpinan spiritual (Ayranci \& Semercioz, 2011). Tingkat evluasi diri (iman) tidak berhubungan secara signifikan terhadap perilaku karyawan (Barhem et al., 2009). Sementara pengaruh ethical climate terhadap perilaku etis, hasil penelitian ini sesuai dengan penelitian Deshpande \& Joseph (2009) dan Kim, Miao, \& Park (2015) yang menyatakan bahwa ethical climate memiliki hubungan dan pengaruh yang positif dan signifikan tehadap ethical behavior.

\section{KESIMPULAN}

Agama dan keberagamaan serta ethical climate memiliki hubungan dan pengaruh yang kuat terhadap perilaku etis. Pada hakikatnya Agama dan keberagamaan serta ethical climate mampu meningkatkan pencapaian dan kualitas perilaku. Oleh karena itu, orang yang religius serta berada pada iklim etis yang baik akan melakukan aktivitas dengan cara yang sesuai dengan aturan yang ada. Pada akhirnya, religiusitas dan iklim etis yang baik akan mempengaruhi perilaku. Religiusitas individu mampu berperan sebagai faktor-faktor yang membedakan dengan individu yang lain, maka itu akan menimbulkan konsekuensi dari perbedaan dalam pencapaian perilaku. Sikap dan perilaku sebagai akibat dari 
religiusitas akan mendorong orang untuk bertindak dalam kinerja yang proaktif, inovatif dan unggul.

\section{DAFTAR PUSTAKA}

Ahmad, W. M. W., Rahman, A. A., Ali, N. A., \& Seman, A. C. (2008). Religiousity and banking selection criteria among Malays in Lembah Klang. Jurnal Syariah, 16(2), 279-304.

Alam, S. S., Janor, H., Zanariah, Wel, C. A. C., \& Ahsan, M. N. (2012). Is religiosity an important factor in influencing the intention to undertake Islamic home financing in Klang Valley? World Applied Sciences Journal, 19(7), 1030-1041. http://doi.org/10.5829/idosi.wasj.2012.19.07.392

Alam, S. S., Mohd, R., \& Hisham, B. (2011). Is religiosity an important determinant on Muslim consumer behaviour in Malaysia? Journal of Islamic Marketing, 2(1), 83-96. http://doi.org/DOI 10.1108/17590831111115268

Allport, G. W. (1967). The religious context of prejudice. Pastoral Psychology, 18(5), 20-30. http://doi.org/10.1007/BF01762402

Allport, G. W., \& Ross, J. M. (1967). Personal religious orientation and prejudice. Journal of Personality and Social Psychology, 5(4), 432-443. http://doi.org/10.1037/h0021212

Aristoteles. (1953). The Ethics of Aristotle: The Nichomachean Ethics. (J. A. K. Thomson, Ed.). England: Penguin Books.

Ayranci, E., \& Semercioz, F. (2011). The relationship between spiritual leadership and issues of spirituality and religiosity: A study of top Turkish managers. International Journal of Business and Management, 6(4), 136-149. http://doi.org/10.5539/ijbm.v6n4pl36

Bakar, A., Lee, R., \& Hashim, N. H. (2013). Parsing religiosity, guilt and materialism on consumer ethics. Journal Islamic Marketing, 4(3), 232-244. http://doi.org/DOI 10.1108/JIMA-04-2012-0018

Barhem, B., Younies, H., \& Muhamad, R. (2009). Religiosity and work stress coping behavior of Muslim employees. Education, Business and Society: Contemporary Middle Eastern Issues, 2(2), 123-137. http://doi.org/DOI $10.1108 / 17537980910960690$

Barnett, T., Bass, K., \& Brown, G. (1996). Religiosity, ethical ideology, and intentions to report a peer's wrongdoing. Journal of Business Ethics, 15(11), 1161-1174. http://doi.org/10.1007/BF00412815

Beit-Hallahmi, B., \& Argyle, M. (1997). The psychology of religious behaviour, 
200 MODERNISASI, Volume 11, Nomor 3, Oktober 2015

belief and experience. London: Routledge.

Bellah, R. N. (1991). Beyond belief: Essays on religion in a post-traditionalist world. London: University of California Press, Ltd.

Bertens, K. (2000). Pengantar etika bisnis. Yogyakarta: Kanisius.

Boone, J., Khurana, I. K., \& Raman, K. K. (2012). Religiosity and tax avoidance. The Journal of the American Taxation Association, 35(1), 121022143747007. http://doi.org/10.2308/atax-50341

Caird, D. (1987). Religiosity and personality: are mystics introverted, neurotic, or psychotic? The British Journal of Social Psychology / the British Psychological Society, 26 ( Pt 4)(1987), 345-346.

Clark, J. W., \& Dawson, L. E. (1996). Personal religiousness and ethical judgements: An empirical analysis. Journal of Business Ethics, 15(3), 359372. http://doi.org/10.1007/BF00382959

Cornwall, M., Albrecht, S. L., Cunningham, P. H., \& Pitcher, B. L. (1986). The dimensions of religiosity: A conceptual model with an empirical test. Review of Religious Research, 27(3), 226-244. http://doi.org/10.2307/3511418

Cullen, J. B., Victor, B., \& Bronson, J. W. (1993). The ethical climate questionnaire: An assessment of its development and validity. Psychological Reports. http://doi.org/10.2466/pr0.1993.73.2.667

Deshpande, S. P., \& Joseph, J. (2009). Impact of emotional intelligence, ethical climate, and behavior of peers on ethical behavior of nurses. Journal of Business Ethics, 85(3), 403-410. http://doi.org/10.1007/s10551-008-9779-z

Desriani, R. (1993). Persepsi akuntan publik terhadap kode etik akuntan indonesia. Pascasarjana Universitas Gadjah Mada Yogyakarta (Tesis tidak dipublikasikan).

Dollahite, D. (1998). Fathering, faith, and spirituality. The Journal of Men's Studies, 7(1), 3-15. http://doi.org/10.3149/jms.0701.3

Glock, C. Y. (1962). On the study of religious commitment. Religious Education, 57(sup4), 98-110. http://doi.org/10.1080/003440862057S407

Griffin, R. W., \& Ebert, R. J. (2007). Bisnis. Jakarta: Erlangga.

Hunt, S. D., \& Vitell, S. (1986). A general theory of marketing ethics. Journal of Macromarketing, 6(1), 5-16. http://doi.org/10.1177/027614678600600103

Johnson, B. R., Jang, S. J., Larson, D. B., \& Li, S. De. (2001). Does adolescent religious commitment matter? A reexamination of the effects of religiosity on 
delinquency. Journal of Research in Crime and Delinquency, 38(1), 22-43.

Karami, M., Olfati, O., \& Dubinsky, A. J. (2014). Influence of religiosity on retail salespeople's ethical perceptions: the case in Iran. Journal of Islamic Marketing, 5(1), 144-172. http://doi.org/DOI 10.1108/JIMA-12-2012-0068

Khomsiyah, \& Indriantoro, N. (1998). Pengaruh orientasi etika terhadap komitmen dan sensitivitas etika auditor pemerintah di DKI Jakarta. Jurnal Riset Akuntansi Indonesia, 1(1), 13-28.

Kidwell, J. M., Stevens, R. E., \& Bethke, A. L. (1987). Differences in ethical perceptions between male and female managers: Myth or reality? Journal of Business Ethics, 6(6), 489-493. http://doi.org/10.1007/BF00383291

Kim, M. Y., Miao, Q., \& Park, S. M. (2015). Exploring the relationship between ethical climate and behavioral outcomes in the Chinese Public Sector: The mediating roles of affective and cognitive responses. International Journal of Business, Humanities and Technology, 5(3), 88-103.

Kreitner, R., \& Kinicki, A. (2001). Organizational behavior. New York: McGrawHill.

Malhotra, N. K. (2004). Marketing research: An applied orientation. New Jersey: Pearson Education, Inc.

Malhotra, N. K. (2010). Markerting research (6 ed). United Stated of America: Prentice Hall, Inc.

McDaniel, S. W., \& Burnett, J. J. (1990). Consumer religiosity and retail store evaluative criteria. Journal of the Academy of Marketing Science, 18(2), 101112. http://doi.org/10.1007/BF02726426

Mcmahon, T. F. (1986). Creed, cult, code and business ethics. Journal of Business Ethics, 5(6), 453-463.

Mokhlis, S. (2009). Relevancy and measurement of religiosity in consumer behavior research. International Business Research, 2, 75-84.

Rehman, A.-, \& Shabbir, M. S. (2010). The relationship between religiosity and new product adoption. Journal of Islamic Marketing, 1(1), 63-69. http://doi.org/10.1108/17590831011026231

Ruiz-Palomino, P. P., \& Martínez-Cañas, R. P. (2011). Corporate ethics and ethical behaviour: The significant function of top management role modelling. The Review of Business Information Systems, 15(5), 69-74. Retrieved from http://search.proquest.com/docview/900729053?accountid=14549\nhttp://hl5 yy6xn2p.search.serialssolutions.com/?genre=article\&sid=ProQ:\&atitle=Corp orate+Ethics+And+Ethical+Behaviour:+The+Significant+Function+Of+Top 
202 MODERNISASI, Volume 11, Nomor 3, Oktober 2015

+ Management + Role + Modelling\& title $=$ The + Review +

Schutte, J. W., \& Hosch, H. M. (1996). Optimism, religiosity, and neuroticism: A cross-cultural study. Personality and Individual Differences, 20(2), 239-244.

Sekaran, U., \& Bougie, R. (2013). Research methods for business: A skill building approach (6th ed.). Singapore: John Wiley \& Sons, Inc.

Stark, R., \& Glock, C. Y. (1968). American piety: The nature of religious commitment. California: University of California Press.

Sugiyono. (2007). Metode penelitian bisnis (Pendekatan kuantitatif, kualitatif, dan $R \& D)$. Bandung: Alfabeta.

Suseno, F. M. (1987). Etika dasar. Yogyakarta: Kanisius.

Umar, H. (2008). Metode penelitian untuk skripsi dan tesis bisnis (1 ed). Jakarta: Rajawali Pers.

Weaver, G. R., \& Agle, B. R. (2002). Religiosity and ethical behavior in organizations: A symbolic interactionist perspective. Academy of Management Review, 27(1), 77-97. http://doi.org/10.5465/AMR.2002.5922390 